\author{
ANNA SCHMIDT \\ Uniwersytet im. Adama Mickiewicza \\ w Poznaniu
}

\title{
A CHILD FROM AN ALCOHOLIC FAMILY IN A SCHOOL ENVIRONMENT
}

\begin{abstract}
Schmidt Anna, A Child from an Alcoholic Family in a School Environment [Dziecko z rodziny alkoholików w środowisku szkolnym]. Studia Edukacyjne nr 50, 2018, Poznań 2018, pp. 453-462. Adam Mickiewicz University Press. ISSN 1233-6688. DOI: 10.14746/se.2018.50.30

The article concerns the child from an alcoholic family in a pre-school environment. The author presents a theoretical introduction on definitions important for understanding the subject, then addresses the subject of social pathology as a factor disturbing the durability of the family system. The topic of social roles in the alcoholic family and their impact on the child's socialization process continue to arouse interest. Another issue raised in the article is the topic of co-dependence, starting from the general definition and understanding of the concept and ending with the impact of this phenomenon on the child's functioning. The issue analyzed and reflected is as follows: a child from an alcoholic family as a student - in particular in relationships with teachers and peers. The author reflected moreover on the possible difficulties a child in a pathological family may encounter in the school environment, as well as on suggested practical solutions and a support network that may help the individual and its immediate environment to fight against difficulties and to motivate change. The article has an introduction and ending, which aptly sums up the issues dealt with.
\end{abstract}

Key words: alcoholic family, child from alcoholic family, child in school environment, social pathology, co-addiction, help and support

\section{Introduction}

In contemporary world we can observe numerous problems that the most important social cell - the family - is struggling with. It's include not only financial problems, or those related to its durability, but also problems resulting from various types of pathologies such as alcoholism, drug abuse or prostitution. Often, they are generally belittled, and the family, which is unable to deal with them, falls into worse and worse states that affect all its mem- 
bers, especially the youngest - children. In this way, they project their actions, which results in disturbed development and deprives the "proper start" of child. They often interfere the fluent of child cognitive processes related to learning and functioning in the school and peer environment, but also basic physiological needs or those of a higher order - the need of love, belonging or security. It is very important to react and take all activities to correct the pathological family situation and prevent possible negative effects from the very beginning.

In this article, I focused on one of many pathologies related to the modern family, namely alcoholism. I started with the theoretical part, in which I attempted to define basic notions and the concept of social pathology as a factor disturbing the durability of the family system.

In the next part I focused on the analysis of the school everyday life of a child from an alcoholic family and the need of support, which should be offered by many individuals and institutions.

The topic concerning a child from an alcoholic family is very extensive, it is impossible to describe and thoroughly analyze all issues that concern it. However, I hope that I managed to raise the most important issues and draw attention to topic which are worth reflecting.

\section{Social pathology as a factor disturbing the durability of the family system}

The phenomenon of social pathology affects many individuals, and also refers to their functioning among other people and social environments in which this person associates. The concept of social pathology concerns various groups of people and is closely related to changes occurring in society.

There are many definitions of this concept. According to M. Lipka,

social pathology is understood as a specific state of attitudes, behaviors and life situations of young people, which are harmful to historically conditioned progress and cause negative consequences for the comprehensive development of an individual, group or society as a whole, and fail to observe applicable laws, moral, manners and cultural norms as well as rejecting or disrespecting the values objectively consistent with the values of the individual and the general public at a given stage of the country's development. ${ }^{1}$

In my opinion, this definition very aptly characterizes this negative phenomenon and even though the author wrote it in reference to young people, it can be applied to adults in the same way. In a different way, the concept of so-

${ }^{1}$ M. Lipka, Zjawiska patologii społecznej wśród młodzieży, Warszawa 1977, p. 15-16. 
cial pathology is defined by W. Okoń, who treats it as a science about causes, symptoms and combating diseases such as crime, drunkenness or drug abuse occurring in society. ${ }^{2}$ However, in the meaning of V. Kavolis, these are "destructive and self-destructive behaviors of people, groups or entire societies". ${ }^{3}$

The term of "social pathologies" is connected with characteristic phenomena that are differently qualified by researchers. M. Szczepański for socially pathological phenomena recognizes: suicides, toxicants and drug addiction, juvenile delinquency, violence and aggression at school, alcohol and nicotine initiations, domestic violence, prostitution, new religious groups, as well as subcultures and counter-cultures. ${ }^{4}$ Another division is presented by A. Kurkowski, who includes social phenomena such as: destructive behaviors against the integrity of other people, destructive behavior directed against property and material well-being, behaviors having an escape character, as well as self-destructive behaviors, such as drug addiction, alcoholism or suicide. ${ }^{5}$

So, we can conclude that social pathologies are all negative behaviors, deviating from the norm, causing unpleasant effects, often associated with acts of self-destruction, both in the committing pathological acts socially by individual, but also to the society and its closest surroundings. The pathological phenomena occurring in Polish society include:

- alcoholism,

- drug addiction,

- prostitution,

- sects,

- youth subcultures,

- begging,

- violence,

- crime understood as a set of acts that are legally prohibited, and for committing them punishable by the penalty specified in the act.

Above, I present only some pathological phenomena and their short characteristics, but we should be aware that the list is much longer, and each of item contained affect the stability of the individual's life as well as all system in which it exist.

${ }^{2}$ W. Okoń, Stownik pedagogiczny, Warszawa 1990, p. 221.

3 Z. Ptaszyński, H. Wróblewska, Patologia wśród dzieci i młodzieży, Warszawa 1998, I quoteafter: P. Migała, Wybrane elementy patologii społecznej w aspekcie ich uwarunkowań, Józefów 2011, p. 6.

${ }^{4}$ M. Szczepański, Polska młodzież: między norma a patologia społeczną. Próba socjologicznego portretu zjawisk patologicznych, [in:] Psychospoteczne uwarunkowania zjawisk dewiacyjnych wśród młodzieży w okresie transformacji ustrojowej w Polsce, Eds. H. Machel, K. Wszeborowski, Gdańsk 1999, p. 27-42.

${ }^{5}$ A. Podgórecki (Ed.), Zagadnienia patologii społecznej, Warszawa 1976, p. 315-343. 


\title{
A child from alcoholic family as a student - relations with teachers and peer environment
}

\begin{abstract}
Depending on the severity of parental alcoholism and other variables, alcoholic children show very numerous physical, psychological and emotional characteristics that affect in every aspect, how these children perform within the educational system. This applies to attendance, classroom behavior, grades obtained, relationships with peer groups, and involvement in extra-curricular activities. ${ }^{6}$
\end{abstract}

The school environment for a child from alcoholic families often becomes a kind of asylum that not only allows him to feel safe and satisfy basic needs of a human being, such as physiological needs - such as overcoming hunger by meals provided by a given institution, but also in accordance to the needs mentioned in the pyramid of A. Maslow, it allows to overcome successive levels, which include the needs of belonging and love as well as respect and self-acceptance. ${ }^{7}$ This is due to the relationships established with teachers and peer contacts.

The teacher has a very important role in the life of every child, and in particular in the life of a child from a pathological family. However, the relations between them are not always correct, which may be due to the teacher's reluctance because of e.g.: aggressive behavior of the student, or braking the rules, applicable norms and principles. Consequently, the child does not receive proper support from the teacher, which, according to the research conducted by E. Dudek, is a basic step towards reducing difficulties and school failures. The author emphasizes the role of the teacher's direct help in completing delays as well as educational deficits of the child, but also involvement in organizing extracurricular education and various forms of support. E. Dudek also draws attention to other tasks resting on the shoulders of the teacher, which includes: shaping respect and recognition for knowledge and intellectual values, but also arousing the desire for further action. ${ }^{8}$

Very important for each child functioning in the school environment are also relationships with peers. As it can be seen from M. Kostanecka's research, the position of a child from an alcoholic family in a peer group is very low. These children meet with reluctance on the part of their colleagues, which confirms the result obtained during the study with the plebiscite of kindness and aversion, in which the rate of popularity of students from families affected by alcoholism was lower than the class average and definitely lower than the chil-

\footnotetext{
${ }^{6}$ M. Szczepkowska, Wptyw alkoholizmu rodziców na sytuację szkolnq dziecka, in: https:// www.4lomza.pl/index.php?wiad=5390, [12.01.2018].

7 J. Strelau (Ed.), Psychologia. Podręcznik akademicki, Gdańsk 2000, p. 64.

8 E. Dudek, Dziecko z rodziny alkoholowej w szkolne, http:/ / www.publikacje.edu.pl/publikacje.php?nr=3962, [12.01.2018].
} 
dren from the control group. It can be concluded that the educational situation and the atmosphere prevailing in the family home determines the child's development process and the acquisition of appropriate characteristics and habits, as well as shaping the right attitudes, which are particularly valued in peer groups, thus determining the child's position among others. ${ }^{9}$ Behaviors that significantly affect the situation of a child in the group may include activities that deviate from the norm, including: aggressive behavior in the group, isolation from peers, fights with other children, unwilling cooperation, frequent quarrels, violation of norms and principles legal issues, lies, thefts, destructive, disobedient and rebellious behavior, as well as truancy, hyperactivity and psychoactive substance abuse. ${ }^{10}$ Basing on the research and observation of the B. Markowska's diagnosis sheet, the behavior of unpopular students in peer groups was characterized, usually from pathological families. It is reported that they are suspicious, fearful, nervous, changeable in the mood, and sometimes even aggressive. Direct factors that affect such a child's functioning are considered to be bad relations in the family affected by alcohol addiction, lack of proper care and love, but also a good parent's example and safety. ${ }^{11}$

Children grow in an atmosphere of nervous tension, uncertainty and fear. Social maturation is delayed, difficulties in establishing social relations with peers arise. These children are offensive, aggressive, behave noisily to attract the attention of their peers or withdraw from the life of the class, avoid contacts and condemn to isolation. All this must have a negative impact on their position and low popularity in the classroom. ${ }^{12}$

\section{Problems in the school environment}

Parental addictions can affect the child's physical development and its social adjustment problems in various ways, as well as the increase of aggression and stress levels and the deterioration of cognitive functioning. Often, they also become victims of negligence, numerous abuses and violent behavior. ${ }^{13}$ No wonder that the school becomes a place of asylum for them, where they can for a moment break away from the sad home reality. However, they

${ }^{9}$ M. Kostanecka, Sytuacja szkolna dzieci z rodzin dotkniętych alkoholizmem, Warszawa 1986, p. 43-45. Read also publications written by: W. Ambrozik, J. Pierera, E. Żabczyńska, M. Ochmański, W. Sawicki.

10 B.E. Robinson, Pomoc psychologiczna dla dzieci alkoholików, p. 122.

11 M. Kostanecka, Sytuacja szkolna, p. 44.

12 Ibidem, p. 44-45.

13 Ibidem, p. 199-201, M. Ochmański in his book: Losy młodzieży z rodzin alkoholicznych $i$ jej charakterystyka psychospołeczna, Ciechanów 1987, points out that children of parents who abuse alcohol are physically weaker (they are smaller, have a lower body weight). What's more, they also show delays in psychomotor development as well as behavioral disorders, p. 50-51. 
do not always meet with understanding and encounter further obstacles, with which they are not always able to cope skillfully.

Problems that a child in an alcoholic family faces in a school environment can be divided into those related to the course of the educational process, but also to adaptive processes, including peer relationships and manifested adverse social behaviors. B.E. Robinson considers the most popular problems of children from alcoholic families school: lower intellectual abilities; worse verbal skills and a lower level of understanding of the text; worse results in learning, worse results of tests for intelligence; inferior efficiency of perceptual-motor coordination, memory and vocabulary; frequent changes to the schools he/she attends, worse attendance at school, frequent repetition of the same class; problems with concentration; restless and impulsive behavior; more frequent visits to a school psychologist or counseling center compared to other pupils; and, in the case of children from low-income alcohol families, frequent removal from school due to various factors, such as aggressive behavior - these pupils are graduating high school rarely. ${ }^{14}$

Starting from problems related to the course of educational processes, it has been proved that children from alcoholic families show a lower level of intelligence than their peers functioning in normal conditions. ${ }^{15} \mathrm{M}$. Ochmański also carried out research on the differences between the level of aptitude on the verbal scale, as well as on the non-literal scale. On this basis, he said that these children have difficulties with expressing their own thoughts, and by limited contact with adults, their vocabulary and concepts are often very poor, which hinders cognitive and educational processes. Pupils from pathological families also have less developed ability to think on particulars and associate facts presented with graphics, as well as less developed skills in material analysis and synthesis, the pace of visual-motor learning and spatial organization of perceived material. ${ }^{16}$ They also show a slower development of intellectual talents and show a lower level of motivation to learn - what is the reason for the difficult educational conditions at home and the lack of parent's interest in school duties and the achievements of child. ${ }^{17}$

14 B. E. Robinson, Pomoc psychologiczna dla dzieci alkoholików, p. 106-117.

15 The level of intelligence of children from alcoholic families is respectively 88 and 103 on the overall Wechsler scale. Also on the verbal scale, the IQ is lower - 91 and 108, and in the non-verbal scale it is 81 and 98. "The reason for this state of affairs may be a weakened child's nervous system, emotional disturbances, culturally low level of family background, pedagogical neglect, as well as also personality traits such as: lack of perseverance, ambition and self-confidence, low resistance to school failure, hyperactivity, inhibitions, etc. Limited contact between these children and adults does not allow to enrich the resources of words and concepts, as well as news". M. Ochmański, Losy młodzieży z rodzin, p. 81.

16 Ibidem.

17 Ibidem, p. 73-77. 
The summary might be this quotation:

school grades depend to a large extent on living conditions that obstruct or facilitate school education of a child. Talents and interests, and above all the lack of emotional inhibition, make schooling and its effects much better. ${ }^{18}$

Another group of difficulties that the child from an alcoholic family faces in a school environment are problems with adaptation, proper functioning and establishing contacts with other people. In the assessment of teachers, these students usually display the following set of features: timidity, crying, insecurity, submissiveness and depression. ${ }^{19}$ They also usually manifest antisocial behavior, often aggressive and arrogant. Children from alcoholic families are usually very inhibited, they display passivity towards their colleagues or teachers, and this all affects their social relations and makes them often feel ridiculed and rejected. It also happens that children from pathological families make numerous educational difficulties, ${ }^{20}$ which is associated with teachers' reluctance towards them and the lack of willingness to take any interaction. "Kessel and Walton (1967) believe that alcohol abuse by parents has a generally negative impact on the child's psychophysical development. This is reflected primarily in the personality development of the sons of fathers abusing alcohol, characterized by their "passive-aggressive " personality, manifesting themselves in difficulties in specifying the aspirations and lack of the ability to control aggression".

Students from pathological families are in a very difficult life situation, their functioning is often difficult or even disturbed. That is why it is so important to recognize and diagnose the child's problems as early as possible, and thus provide him with appropriate assistance, provide support and take all actions to minimize the likelihood of further failures.

\section{Support network at school and beyond}

M. Kostanecka states that in the case of organizing help for children from pathological families, various types of care and educational tasks should be taken into account. These include: support for an addicted family member and specialist treatment; taking care of both the child and his family (it should include financial assistance, but also feeding or equipping with necessary

\footnotetext{
18 M. Kostanecka, Sytuacja szkolna dzieci, p. 33.

19 M. Ochmański, Losy młodzieży z rodzin alkoholicznych, p. 72.

${ }^{20} \mathrm{H}$. Kaja defines educational difficulties as "skewed, socially undesirable forms of behavior in children, unfavorable for their further psychological development, hindering intercourse and cooperation mainly in the field of education" (M. Kostanecka, Sytuacja szkolna dzieci, p. 38).
} 
products such as clothing, cleaning products, etc.); preventing and fighting possible deviant behaviors manifested by both the child and his parents; shaping good relations in the family; helping the child overcome school difficulties and taking measures to provide assistance in this regard; stimulating the child's educational aspirations; care for shaping good relations of the child with both teachers and the surrounding peer environment; organizing forms of spending free time. ${ }^{21}$

W. Sawicki emphasizes that:

The life of children of alcoholics is often a tragic strand of horrible days and much more horrible nights. From an early age, they come into contact with vulgar vocabulary, fights, fights and other attacks of violence. ${ }^{22}$

That is why it so important to receive appropriate support and conditions for proper functioning and further action at school - "second home" of child.

The first to observe the pupil's problems and to take up supporting activities are the teachers, especially the educator, as well as the school educator. They have a significant role in organizing help and various types of support for a child coming from a family with an alcohol problem.

Educator - very important role in school, but it is not only about taking care of the good functioning of the institution, but rather about the individuals that each student represents.

Educator in his work should aim to develop mental and personal interests of pupils in the intellectual, mental, health, aesthetic and moral dimension; teach respect and tolerance for others, prepare pupils to recognize moral values, shape in them the attitude of dialogue, the ability to listen to others, understand their views. ${ }^{23}$

Another person who is very dependent on the level of support and help coming from the school environment in relation to the student from the pathological family is the school educator. According to the definitions given by J. Dutkiewicz, it is "a person employed at school to supplement, deepen and extend didactic-educational and caring activities carried out by teachers", elsewhere describes it as "the position of a teacher appointed to provide educational care for youth in school and outside school and to coordinate cooperation with the home". ${ }^{24}$

However, when we analyze the process of helping a child in a family with an alcohol problem, it is not possible to take into account only the teacher -

${ }^{21}$ M. Kostanecka, Sytuacja szkolna dzieci, p. 46-47.

${ }^{22}$ I quoteafter: M. Ludwiczak, Alkoholizm rodziców a sytuacja społeczna dzieci, in: http:// www.poradnikpr.info/?page=nowosc\&arti_id $=4168 \&$ paged $=43$, [13.01.2018].

${ }_{23}$ A. Nowak, Rola wychowawcy w edukacji uczniów - referat, Konin 2003, p. 7.

${ }^{24}$ J. Dutkiewicz, Pedagog szkolny - czyli kto? in: www.zsos6gliwice.edu.pl/download/.../ ped_cz_kto.doc, [13.01.2018]. 
the educator and the school educator. It should be emphasized that every adult working in a this institution, after observing disturbing manifestations of behavior, low student's achievements or problems with child functioning in the group, regardless of whether it is a teacher, director or school psychologist should react to give child the best start in further life and correct development. It is also worth mentioning the branches operating in the communes, poviats, provinces, and all of Poland, i.e. Municipal Centers for Family Assistance, Municipal Social Assistance Centers, Family Counseling Centers, Foundations, Associations, Environmental Centers, and Treatment Counseling and Addiction Dependencies, where you can also look for help and support.

\section{Conclusions}

The child is often referred to a miracle, treasure or gift. However, we regret to see that society is not always able to appreciate this gift. It is worth to say the truth that in contemporary world seems to be forgotten is: the family has the greatest and primary responsibility for satisfying the child's basic needs and its proper functioning and development. As Michel Quoist claimed, "Children more than others need to be absolutely sure that they are loved by those who say they love them" ${ }^{25}$ So the family faces a great challenge to create the well conditions for its members and enable them to develop harmoniously. However, is not always able to deal with this challenge. That is why it is so important to offer different forms of support and help from various organizations and institutions. Finally, I would like to reflect on the words spoken by Ronald Russell:

Today's shy child is the one from which we laughed yesterday.

Today's cruel child is the one that we were beating yesterday.

Today's child who cheats is what we did not believe yesterday.

Today's rebellious child is the one we tormented yesterday.

Today's child in love is the one we fondled yesterday.

Today's wise child is the one whom we encouraged yesterday.

Today's cordial child is the one whom we showed love yesterday.

Today's wise child is the one we raised yesterday.

Today's forgiving child is the one whom we forgave yesterday.

Today's man, who lives with love and beauty, is a child who was happy yesterday. ${ }^{26}$

I think that this fragment in a very meaningful way illustrates the role of an adult person in the life of every child and seems to be particularly impor-

${ }^{25}$ Doi: http:/ / 21malina.blox.pl/html/1310721,262146,21.html?951261, [access: 13.01.2018].

${ }^{26}$ Doi:http://moblo.pl/profile/teczyswiat,,page,4, [access: 13.01.2018]. 
tant in relation to people who in their life will take a job as a teacher, pedagogue, psychologist, social therapist or health promoter, where every day they will take care of proper development and functioning of children, at various stages of their lives.

\section{BIBLIOGRAPHY}

Cierpiałkowska L., Alkoholizm. Małżństwa w procesie zdrowienia, Poznań 1997.

Cierpiałkowska L., Alkoholizm. Przyczyny - Leczenie - Profilaktyka, Poznań 2000.

Cierpiałkowska L., Oblicza wspótczesnych uzależnień, Poznań 2006.

Dudek E., Dziecko z rodziny alkoholowej w szkolne, http:/ / www.publikacje.edu.pl/publikacje.php?nr=3962.

Dutkiewicz J., Pedagog szkolny - czyli kto?, www.zsos6gliwice.edu.pl/download/.../ped_ cz_kto.doc.

Dziewiecki M. (Ed.), Nowe przestanie nadziei, Warszawa 2000.

Kostanecka M., Sytuacja szkolna dzieci z rodzin dotkniętych alkoholizmem, Warszawa 1986.

Lipka M., Zjawiska patologii społecznej wśród młodzieży, Warszawa 1977.

Ludwiczak M., Alkoholizm rodziców a sytuacja społeczna dzieci, in: http:/ /www.poradnikpr. info $/$ ?page $=$ nowosc\&arti_id $=4168 \&$ paged $=43$.

Margasiński A., Wspótuzależnienie i syndrom DDA w kontekście teorii systemów rodzinnych Bowena, [in:] Leczenie alkoholików i członków ich rodzin, Ed. K. Gąsior, J. Chodkiewicz, Kielce 2010.

Mellibruda J., Sobolewska Z., Koncepcja i terapia wspótuzależnienia, Alkoholizm i Narkomania, 1997, 3, 28.

Migała P., Wybrane elementy patologii społecznej w aspekcie ich uwarunkowań, Józefów 2011.

Nowak A., Rola wychowawcy w edukacji uczniów - referat, Konin 2003.

Ochmański M., Losy młodzieży z rodzin alkoholicznych i jej charakterystyka psychospołeczna, Ciechanów 1987.

Okoń W., Stownik pedagogiczny, Warszawa 1990.

Okońska-Walkowicz A., Nauczyciel wychowawca, http://www.nw.sto.org.pl/down/ Anna_Okonska_Walkowicz-Nauczyciel_wychowawca.pdf.

Podgórecki A. (Ed.), Zagadnienia patologii społecznej, Warszawa 1976.

Ptaszyński Z., Wróblewska H., Patologia wśród dzieci i młodzieży, Warszawa 1998.

Robinson B. E., Pomoc psychologiczna dla dzieci alkoholików, Warszawa 2008.

Ryś M., Role petnione w rodzinach z problemem alkoholowym a poczucie własnej wartości i relacje interpersonalne z najbliższymi u Dorostych Dzieci Alkoholików, in: www.stowarzyszeniefidsetratio.pl/Presentations0/08-2011-4.pdf.

Strelau J.(Ed.), Psychologia. Podręcznik akademicki, Gdańsk 2000.

Szczepański M., Polska młodzież: między norma a patologia spoteczną. Próba socjologicznego portretu zjawisk patologicznych, [in:] Psychospołeczne uwarunkowania zjawisk dewiacyjnych wśród młodzieży w okresie transformacji ustrojowej w Polsce, Eds. H. Machel, K. Wszeborowski, Gdańsk 1999.

Szczepkowska M., Wptyw alkoholizmu rodziców na sytuację szkolna dziecka, in: https:/ / www. 4lomza.pl/index.php? wiad $=5390$.

Sztajner A., Dziecko w rodzinie z problemem alkoholowym, Warszawa 1994.

Sztander W., Dzieci w rodzinie z problemem alkoholowym, Warszawa 2006.

Woronowicz B., Bez tajemnic o uzależnieniu i ich leczeniu, Warszawa 2001.

Woydyłło E., Aby wybaczyć. Poradnik dla rodzin alkoholików, Warszawa 1993. 